\title{
Testi és társadalmi nem, szexuális orientáció
}

Body and gender identity, sexual orientation

Szerzők: Vitrai Sára®

Beküldve: 2016.09.05.

\begin{abstract}
Összefoglaló: A szexuális nevelés témájában gyakran felmerülnek a nemi szerepekhez, szexuális orientációhoz hasonló kifejezések, amelyeknek rövid magyarázatát adja ez a cikk. Az emberek szexuális vágyai és adottságai sokfélék lehetnek, amit fontos észben tartanunk, amikor szexuális nevelésről beszélünk. Amennyiben csak cisznemű, heteroszexuális és monogám emberekről ejtünk szót, sok fiatal kívülállónak érezheti magát, vagy úgy gondolhatja, az elhangzott tájékoztatás nem vonatkozik rá, esetleg a számára releváns információ nem is hangzik el.

Kulcsszavak: testi identitás, társadalmi nemi identitás, nemi szerepek, szexuális orientáció, szexuális gyakorlat

Summary: In relation to the topic of sexual health terms like gender roles, sexual orientation are often mentioned. A short glossary of these terms are given in this article. People's sexual desires and attributes can vary to a great degree which is important to keep in mind when talking about sexual education. If we only talk about cisgender, heterosexual and monogamous people, many young people might feel that they don't belong, think that the information given does not concern them or the information that they need might not even be voiced at all.
\end{abstract}

Keywords: body identity, gender identity, gender roles, sexual orientation, sexual practice

A szexuális nevelés témájában gyakran felmerülnek a nemi szerepekhez, szexuális orientációhoz hasonló fogalmak. Ezekkel a kifejezésekkel azért fontos tisztában lennünk, mert a fiatalok szexuális oktatásával foglalkozó szakembereknek ezek fényében kell megfelelő információt átadni az érintett fiataloknak.

„Mi az a „gender”?

Először is, a sokat emlegetett gender, maga egy társadalom- és politikatudományi fogalom, amit magyarul társadalmi nemi szerepnek vagy társadalmi nemnek szokás fordítani. A gender fogalma a feminizmusban arra szolgál, hogy rávilágítson, a nemi szerepek nem „természetes”, biológiailag adott jellemzők, nem veleszületettek és adottak, tehát a biológiai nemtől különálló fogalomra van szükség a leírásukra. Szemben a genderrel, a biológiai nemünk
- az, hogy milyen kromoszómákkal és nemi szervekkel születünk - adott. A biológiai és társadalmi nem úgy kapcsolódik egymáshoz, hogy az alapján nevelődünk, szocializálódunk és kezeltetünk a társadalomban nőként illetve férfiként, hogy milyen nemi szervekkel (milyen biológiai nemmel) születünk.

De a nemi szerepek nem biológiailag adottak és megváltoztathatatlanok, hanem - legalábbis a legtöbb feminista irányzat szerint - az, amit "nőnek" és "nőiesnek"/,femininnek”, illetve amit „férfinak” és „férfiasnak"/,maszkulinnak" gondolunk, olyan társadalmilag konstruált kategóriák, amelyeket nevelkedésünk, szocializációnk folyamán sajátítunk el. Általában próbálunk ezeknek a nemi szerep-elvárásoknak többé-kevésbé megfelelni, illetve kompenzálni, ha valamilyen szempontból eltérünk attól. Ez fóként azért van, mert ha nem felelünk meg nekik, vagy legalábbis valaki úgy találja, hogy nem felelünk 
meg nekik, akkor negatív visszajelzéseket, „,büntetéseket" kapunk; ezek lehetnek például a kortárs csoportban tapasztalt lenézés és beszólások, de megtestesülhetnek akár fizikai erőszak formájában is a szülők, partner, kortársak vagy idegenek részéről." 1

Ebből a néhány bekezdésből kiindulva nézzük végig, hogy hogyan viszonyul egymáshoz a testi identitás, társadalmi nem és szexuális orientáció.

Először is van mindenkinek egy testi identitása, ami arra vonatkozik, hogy fizikailag milyen a testi felépítése. Lehetnek valakinek férfi vagy női nemi szervei, hormonjai, kromoszómái és ezeknek valamilyen kevert kombinációja is. Interszexnek nevezzük azokat az embereket, akiknek férfi és női nemi szervei vagy hormonjai, vagy kromoszómái is vannak. Például külsőre férfinak néz ki, de van méhe. Célszerű egy számegyenest elképzelnünk, amelynek az egyik felén vannak a biológiailag 100\% férfiak, a másik végén pedig a biológiailag 100\% nők.

A társadalmi nemi identitás vagy gender összefügg, de nem feltétlenül egyezik a testi identitással (ahogy ez a fenti idézetből is kiderül). Valakinek a társadalmi nemi identitásához tartozik az öltözködése, viselkedése (hogy mennyire határozott, együttmúködő stb.), hogy mit gondolunk a számára megfelelő munkának, vagy mennyire szeretnénk, hogy részt vegyen a gyereknevelésben. Az ilyen jellegű társadalmi elvárások kultúránként és koronként változnak. Gender-ből sem csak férfi és nő van, mint ahogy gyerekkorunkban megtanították (szoknya=lány, nadrág=fiú). Az emberek általában a férfiasnak és nőiesnek tartott tulajdonságok valamilyen kombinációját fejezik ki. Amennyiben ismét egy számegyenest képzelünk el, vannak akik az egyik vagy másik végén érzik jól magukat; valakik mozognak ezen az egyenesen (gender fluid, non-binary); mások pedig egyáltalán nem szeretnék ezen egyenes alapján meghatározni önmagukat (gender nonconforming). Azokat, akiknek egyezik a testi és társadalmi nemi identitása (pl. női testi identitás + női gender) nevezzük cisznemüeknek, akiknek nem egyezik, ők a transznemüek (nem összekeverendő azokkal az emberekkel, akik kedvtelésből öltöznek be az ellenkező nemnek: crossdresser).

Az eddig említett fogalmak még csak arról szóltak, hogy az egyén hogyan érzi magát, fejezi ki magát, de még nem határoztuk meg, hogy hogyan/kikkel lépkapcsolatba. Ezt dönti el a szexuális orientáció. Heteroszexuális az, aki a vele ellenkező nemúekhez, míg homoszexuális az, aki a vele azonos nemúekhez vonzódik, és itt sem annyira egyszerü a helyzet, ahogy gondolnánk. Vannak biszexuálisok, akik a hozzájuk hasonló és a tőlük eltérő nemúek iránt is éreznek vonzalmat (akár azonos, akár különböző mértékben). Pánszexuálisnak hívják magukat azok, akik nem testi vagy társadalmi nemi identitáshoz „kapcsolják" vonzalmukat, hanem ezt kizárólag az egyes emberek személyiségtől teszik függővé. Ezen felül nem csak szexuális, hanem romantikus vonzalmat is élhetünk meg mások iránt, és ezek nem feltétlenül járnak együtt. Például lehet valaki heteroszexuális, de biromantikus, vagyis szexuálisan az ellenkező nemúekhez vonzódik, de képes szerelembe esni a vele azonos nemúekkel is. Ne feledkezzünk meg arról sem, hogy nem mindenki érez szexuális vonzalmat mások iránt, vagy ez az átlagosnál gyengébb/kevesebb, ők az aszexuálisok. (A szexuális vonzalom mértéke is rávetíthető egy számegyenesre az egyik végén az aszexuálisokkal a másik végén a hiperszexuálisokkal. Ennek a mértéke is változhat egy ember élete során.) Még az orientáció kérdésköréhez tartozik, hogy vannak, akik egyszerre több ember iránt képesek szexuális és/vagy romantikus vonzalmat táplálni, ők a poliamor emberek. Fontos tisztázni, hogy ebben a kapcsolati berendezkedésben minden résztvevő tisztában van a helyzettel és beleegyezik, tehát nem egyenlő a megcsalással. Nem összekeverendő a poliamoria a poligámiával, amely a több mint két ember közti házasságot jelenti. Ezek általában egy gazdasági/vallási megállapodáson alapulnak és nem feltétlenül a résztvevők szabad választásán.

Gondoljunk bele, aki nem cisznemú, heteroszexuális és monogám, sokszor nehezen talál magának párt, mivel preferenciái nem egyeznek a jelen társadalmunkban „normálisnak” tartott gyakorlattal. Ezért fontos tisztázni, valakinek a szexuális orientációja nem mindig egyezik a szexuális gyakorlatával. Például néhány évtizeddel ezelőtt a homoszexualitás büntetendő volt, ezért akkoriban gyakran előfordult, hogy egy meleg férfi heteroszexuális házasságban élt, és egész életében nem volt férfi partnere. Ez esetben az ő szexuális gyakorlata nem egyezett szexuális orientációjával. 
Amint látjuk, a fentiek alapján az emberek szexuális vágyai és adottságai nagyon sokfélék lehetnek. Ezt fontos szem előtt tartanunk, amikor szexuális nevelésről beszélünk, mert ha csak cisznemű, heterosze- xuális és monogám emberekről ejtünk szót, sok fiatal kívülállónak érezheti magát, vagy úgy gondolhatja, az elhangzott információ nem vonatkozik rá, esetleg számára releváns tartalmat nem is hall.

\footnotetext{
${ }^{1}$ Nogradi W Noa. Genderőrületi gyorstalpaló 1. - gender, szexizmus, patriarchátus. Kettős Mérce, 2016. http://kettosmerce.blog.hu/2016/01/31/genderoruleti gyorstalpalo 1 gender szexizmus patriarchatus); (Elérve: 2016.09.12.)
} 